\title{
A program to increase use of chemoprevention for women with high-risk breast lesions.
}

\section{Citation}

Roche, Constance A., and Kevin S. Hughes. 2012. "A Program to Increase Use of Chemoprevention for Women with High-Risk Breast Lesions." Journal of Clinical Oncology 30 (27_suppl) (September 20): 46-46. doi:10.1200/jco.2012.30.27_suppl.46.

\section{Published Version}

doi:10.1200/jco.2012.30.27_suppl.46

\section{Permanent link}

http://nrs.harvard.edu/urn-3:HUL.InstRepos:36863329

\section{Terms of Use}

This article was downloaded from Harvard University's DASH repository, and is made available under the terms and conditions applicable to Other Posted Material, as set forth at http:// nrs.harvard.edu/urn-3:HUL.InstRepos:dash.current.terms-of-use\#LAA

\section{Share Your Story}

The Harvard community has made this article openly available.

Please share how this access benefits you. Submit a story.

\section{Accessibility}




\title{
JOURNAL OF CLINICAL ONCOLOGY
}

Official Journal of the American Society of Clinical Oncology

\section{A program to increase use of chemoprevention for women with high- risk breast lesions.}

\author{
Constance A. Roche, Kevin S. Hughes \\ Massachusetts General Hospital, Boston, MA \\ Massachusetts General Hospital, Boston, MA
}

Background: Tamoxifen, raloxifene, and exemestane have been demonstrated to reduce risk of breast cancer in high-risk women, but utilization is very low. Among the reasons cited are lack of awareness and reluctance of physicians to prescribe. Women with high-risk breast lesions are generally candidates for chemoprevention and can be evaluated and counseled in a high-risk breast clinic. Knowledge about drugs that can prevent breast cancer may increase uptake among high-risk women.

Methods: In a single practice, women with a diagnosis of atypical ductal hyperplasia (ADH), atypical lobular hyperplasia (ALH), lobular carcinoma in situ (LCIS), or severe atypical ductal hyperplasia/borderline ductal carcinoma in situ are offered an extended visit with a nurse practitioner in the Breast and Ovarian Cancer Risk and Prevention Clinic. The visit includes data collection, patient interview about relevant history and personal preferences, risk assessment, including use of relevant models (via HughesRiskApps.com), and recommendations for surveillance and prevention. Emphasis is placed on understanding of individual risk as well as risks and benefits and appropriateness of chemoprevention and surveillance modalities. Based on personal and family history, women are advised if chemoprevention is appropriate to consider, their choice is made, and they are encouraged to have surveillance in the Breast Clinic.

Results: Since January 2001, 487 women with a diagnosis of ADH, ALH or LCIS, or severe ADH have been evaluated and counseled in the Breast and Ovarian Cancer Risk and Prevention Clinic. 132/487 (27\%) were advised against taking chemoprevention and 355/487 (73\%) were appropriate for chemoprevention. Of those for whom chemoprevention was clinically appropriate, 188/355 (53\%) took one of the medications, or participated in a chemoprevention trial. 53/188 (28\%) did not complete therapy (discontinued at 2 weeks to 54 months) due to preference or side effects. 75 women have completed five years of therapy and 60 are currently on therapy.

Conclusions: When provided with personalized information about breast cancer risk and the pros and cons of chemoprevention, many women will choose to take medication to reduce breast cancer risk.

DOI:10.1200/jco.2012.30.27_suppl.46

Journal of Clinical Oncology 30, no. 27 Supplement (September 2012) 46. 